\title{
Agrobacterium-mediated transformation of melastoma malabathricum and tibouchina semidecandra with sense and antisense dihydroflavonol-4-reductase(DFR)genes.
}

\begin{abstract}
Genetic engineering of a wide variety of plant species has led to the improvement of plant traits. In this study, the genetic transformation of two potentially important flowering ornamentals, Melastoma malabathricum and Tibouchina semidecandra, with sense and antisense dihydroflavonol-4-reductase (DFR) genes using the Agrobacterium mediated method was carried out. Plasmids pBETD10 and pBETD11, each harbouring the DFR gene at different orientations (sense and antisense) and selectable marker npt II for kanamycin resistance, were used to transform $M$. malabathricum and T. semidecandra under the optimized transformation protocol. Putative transformants were selected in the presence of kanamycin with their respective optimized concentration. The results indicated that approximately $4.0 \%$ of shoots and $6.7 \%$ of nodes for M. malabathricum regenerated after transforming with pBETD10, whereas only $3.7 \%$ (shoots) and $5.3 \%$ (nodes) regenerated with pBETD11 transformation. For the selection of T. semidecandra, 5.3\% of shoots and $9.3 \%$ of nodes regenerated with pBETD10 transformation, while only $4.7 \%$ (shoots) and $8.3 \%$ (nodes) regenerated after being transformed with pBETD11. The presence and integration of the sense and antisense DFR genes into the genome of M. malabathricum and T. semidecandra were verified by polymerase chain reaction (PCR) and nucleotide sequence alignment and confirmed by southern analysis. The regenerated putative transformants were acclimatized to glasshouse conditions. Approximately 31.0\% pBETD10-ransformed and 23.1\% pBETD11transformed M. malabathricum survived in the glasshouse, whereas $69.4 \%$ pBETD10transformed and 57.4\% pBETD11-transformed T. semidecandra survived. The colour changes caused by transformation were observed at the budding stage of putative $\mathrm{T}$. semidecandra transformants where greenish buds were produced by both $\mathrm{T}$. semidecandra harbouring the sense and antisense DFR transgenes. Besides that, the production of four-petal flowers also indicated another morphological difference of putative $T$. semidecandra transformants from the wild type plants which produce five-petal flowers.
\end{abstract}

Keyword: Agrobacterium; Melastoma malabatrhicum; Tibouchina semidecandra; Dihydroflavonol-4-reductase; Colour. 